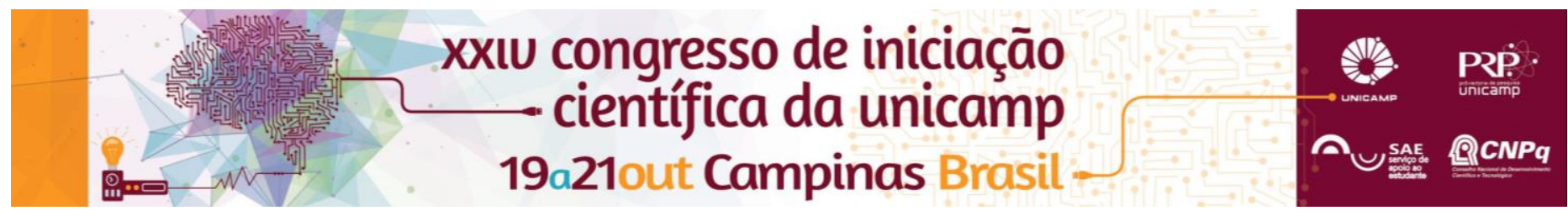

\title{
FARINOGRAPHIC AND ALVEOGRAPHIC PROPERTIES OF WHEAT FLOUR INCORPORATED WITH BUCKWHEAT FLOUR (Fagopyrum esculentum Moench)
}

\author{
Juliana B. Araujo*, Lara T.G.F. Brites \& Caroline J. Steel
}

\begin{abstract}
Buckwheat (Fagopyrum esculentum Moench) is a pseudocereal that has been highlighted in global research for its rich nutritional composition. This study had as objective to investigate the farinographic and alveographic properties of wheat flour (WF) with the incorporation of 30 and $45 \%$ whole grain buckwheat flour (WGBF). The following parameters were evaluated: water absorption (WA), arrival time (AT), dough development time (DDT), stability (S), resistance to extension $(P)$, extensibility $(L)$ and flour strength $(W)$. Differences were observed in farinographic and alveographic behavior with the addition of WGBF. However, it can be predicted that the incorporation of 30 and $45 \%$ of WGBF is possible without causing major damages to parameters such as WA and P, expanding the possibility of the production of breads with the addition of buckwheat flour.
\end{abstract}

\section{Key words:}

buckwheat; farinograph; alveograph.

\section{Introduction}

Buckwheat (Fagopyrum esculentum Moench) is a pseudocereal that has no gluten and contains a variety of nutrients and phenolic compound, the consumption of which is associated with a lower risk of diseases ${ }^{1}$.

The incorporation of raw materials without gluten in breadmaking products alters dough characteristics, usually causing great effects on rheological properties. The farinograph and the alveograph are two devices widely used to assess the behavior of flours.

This study had as objective to investigate the farinographic and alveographic properties of WF with the incorporation of 30 and $45 \%$ WGBF.

\section{Results and Discussion}

Table 1 shows the farinographic properties of WF and of blends with 30 and $45 \%$ WGBF. The flours used had $2.39 \pm 0.15 \%(\mathrm{WF})$ and $24.43 \pm 0.91 \%$ (WGBF) total dietary fiber contents.

Table 1. Farinographic properties of WF and of the blends with 30 and $45 \%$ WGBF.

Blends WA (\%) AT (min) DDT (min) S (min) $\begin{array}{lllll}100 \% \text { WF } & 58.30 \pm 0.57 a & 1.20 \pm 0.07 \mathrm{bc} & 11.80 \pm 0.35 \mathrm{a} & 16.17 \pm 0.87 \mathrm{a}\end{array}$

$\begin{array}{lllll}30 \% \text { WGBF } & 56.93 \pm 0.21 \mathrm{a} & 1.30 \pm 0.17 \mathrm{~b} & 7.07 \pm 0.59 \mathrm{~b} & 9.93 \pm 0.21 \mathrm{~b}\end{array}$

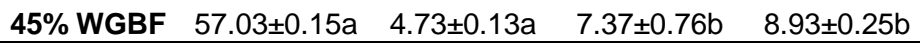

It was observed that the samples did not present significant difference in WA values. Gluten-free raw materials tend to decrease WA; however, when using the WF associated with WGBF, that is rich in fiber, the WA remained the same.

For AT, it can be seen that the blend with $45 \%$ WGBF presented a longer time compared to the other samples, probably due to the higher fiber content, as they have a lower rate of hydration than the proteins ${ }^{3}$

DDT and $S$ followed the same behavior and there was a decrease in the parameters with the addition of 30 and $45 \%$ of WGBF, due to the dilution of gluten in the blends ${ }^{4}$.

Table 2 shows the alveographic properties.

Relative to $\mathrm{P}$, it was observed that the incorporation of $30 \%$ WGBF increased the value of this parameter; and that for $L$, the value decreased in relation to $100 \%$ WF. This behavior was expected, since WGBF has a high fiber content, generating a firm dough with greater resistance to extension (elasticity), but without extensibility, easily breaking 5 .

Table 2. Alveographic properties of WF and of the blends with 30 and $45 \%$ of WGBF.

$\begin{array}{cccc}\text { Blends } & \mathbf{P}(\mathbf{m m}) & \mathbf{L}(\mathbf{m m}) & \mathbf{W}(\mathbf{x 1 0 - 4} \mathbf{~ J )} \\ \mathbf{1 0 0} \% \text { WF } & 100.77 \pm 5.13 \mathrm{~b} & 61.00 \pm 2.65 \mathrm{a} & 271.07 \pm 24.95 \mathrm{a} \\ \mathbf{3 0} \% \text { WGBF } & 128.22 \pm 14.64 \mathrm{a} & 24.33 \pm 3.21 \mathrm{~b} & 133.29 \pm 22.17 \mathrm{~b} \\ \mathbf{4 5} \% \text { WGBF } & \text { n.d. } & \text { n.d. } & \text { n.d. }\end{array}$

The analysis of the blend with $45 \%$ WGBF could not be accomplished by having parameters that were not read by the equipment due to the strength of fibers in the sample.

\section{Conclusions}

With the results of the analyses it can be concluded that the evaluation of farinographic and alveographic properties proved to be important for predicting the behavior of blends, being interesting processing bread with the addition of 30 and $45 \%$ of FSG, because of its nutritional benefits.

\section{Acknowledgements}

To SAE/Unicamp and FAPESP, for the scientific initiation scholarship granted to the student Juliana Araujo Bonadio (period: August/2015 to November/2015 and period: December/2015 to November/2016, respectively).

To CAPES for the PhD scholarship granted to student Lara Tatiane Geremias Ferreira Brites.

To Moinho Paulista, for the donation of the WF used.

${ }^{1}$ COSTANTINI, L., LUKŠIC, L., MOLINARI R., KREFT I., BONAFACCIA G., MANZI L., MERENDINO N. Development of gluten-free bread using tartary buckwheat and chia flour rich in flavonoids and omega-3 fatty acids as ingredientes. Elsevier, 2014.

2 ALMEIDA, E. L.; CHANG, Y. K.; STEEL, C. J. Effect Of Adding Different Dietary Fiber Sources on Farinographic Parameters of Wheat Flour. Cereal Chem., Vol 87, No. 6, 2010.

3 SCHMIELE, M.; JAEKEL, L. Z.; PATRICIO, S. M. C.; STEEL, C. J.; CHANG, Y. K. Rheological properties of wheat flour and quality characteristics of pan bread as modified by partial additions of wheat bran or whole grain wheat flour. International Journal of Food Science and Technology, v.47, 2012.

${ }^{4}$ KATINA, K. (2003). High-fibre baking. In: Bread Making: Improving Quality. Pp. 487-499. Cambridge, UK: Woodhead Publishing Ltd.

5 MÓdEnES, A. N.; SILVA, A. M.; TRIGUEROS, D. E. G. Avaliação das propriedades reológicas do trigo armazenado. Ciênc. Tecnol. Aliment. vol.29 no.3. July/Sept. 2009. 